\title{
Marketing strategies in enrollment management: Direct mail and financial aid
}

\section{Estrategias de marketing en la gestión de inscripción: Correo directo y ayuda financiera}

\author{
Ab, Aldo Maino Isaías, MBA \\ Universidad Internacional del Ecuador, Ecuador \\ Autor para correspondencia: amaino@uide.edu.ec \\ Fecha de recepción: 21 de Diciembtre de 2015 - Fecha de aceptación: 18 de Enero de 2016
}

\begin{abstract}
Resumen
El aumento en instituciones de educación superior ha resultado en la comercializacion de educación superior, el cual ha aumentado la competencia entre las instituciones que proveen este servicio. Las universidades tienen una necesidad económica de reclutar a nuevos estudiantes y retener a los que ya han sido admitidos para asegurar sus ganancias y tener los fondos para seguir ofreciendo sus servicios educativos. Las dos maneras que más utilizan las instituciones de educación superior para atraer estudiantes son por medio de correo directo y ayuda financiera. Se esfuerzan por ofrecerles paquetes financieros atractivos a los estudiantes más calificados para hacer que elijan su universidad en vez de otra. El siguiente artículo describe y analiza los procesos de reclutamiento en la esfera de educación superior.
\end{abstract}

Palabras claves: marketing; educación superior; ayuda financiera

\begin{abstract}
The increase in private institutions of higher education has led to the commercialization of higher education, which has increased the competition between the institutions that provide this service. Universities have an economic need to recruit new students and retain the ones that they have already admitted in order to remain profitable and have the funds to continue offering their educational services. The two main ways that institutes of higher education attempt to entice students are through direct mailings and financial aid. They strive to reach the students that are most likely to be eligible for their institution and offer the most qualified students attractive financial packages that will sway them towards choosing their university over another. The following article describes and analyzes these recruitment processes in the higher education sphere.
\end{abstract}

Key words: marketing; higher education; financial aid 


\section{Introduction}

Marketing and advertising in higher education have radically changed since 1970's. From an environment where public institutions obtained much of their financial support through state and federal funding to the current environment of increased competition with new private institutions that have revolutionized the marketplace and started a period of "commercialization" of higher education. Moreover, the US economic crisis has decreased the state funding for public institutions and has made them not only compete with an aggressive market fight from private universities, but also to start promoting their programs in a different ways that make them able to at least preserve their market share or even grow in order to survive.

The rise of for-profit institutions, especially with online programs degrees, has prompted a new market strategy in enrollment management for the entire higher education sector. For these institutions marketing strategies have positively impacted their enrollment. On average they spend approximately $20 \%$ of their budget in marketing and advertising (Strout, 2006). Student enrollment, retention, and academic performance are making universities to operate more of a business than an academic institution. These strategies are working well for many institutions, considering admission and retention trends.

Marketing in higher education is a form of service marketing. Services are intangible and customers don't know what they are purchasing until after the service has been provided (Clark \& Hossler, 1990). One of the important responsibilities of enrollment management officers is making sure that customers receive what was advertised or marketed. Hossler (1996) credits Mcguire with coining the term enrollment management to explain administrative functions that were being put in place at Boston College in the late 1970's to support institutional enrollment goals.

Colleges and universities have unique characteristics that must be considered in their marketing strategies. These set of strategies are the result of an institutional strategic planning and research; analyzing and selecting target markets and developing a coordinated and appropriate marketing strategies that meet the enrollment goals of each institution.

Among different marketing activities are direct mail, inserts, high school visits and promotions, internet, magazines, newspapers, radio, television, yellow pages, pricing, telemarketing, financial aid, merit aid and awards. The purpose of this study is to describe, analyze and perceive the impact of direct mailing strategies and financial aid strategies as part of the strategic marketing plan and the recruitment institutional goal.

\section{Ethical Marketing of Higher Education}

Higher education is exposed to competition in marketplace conditions where institutions are compelled to compare their offerings with others to attract students. Higher education market is now well established as a global diverse phenomenon (Hemsley-Brown and Oplatka, 2006).

Universities promote education as a commodity, offering successful careers and a wellknown reputation degree. Some marketing strategies take students more as customers and teachers more as service providers. According to Arpan Raney and Zivnuska's (2003) study of 
major US universities found that various non-academic aspects, for instance athletics, contributed greatly to their reputations.

However, marketing and advertising has to be done with caution and questioning. Advertising is an insidious and implicit attack on our ability to develop as a human being and more difficult to isolate and defend against education consumerism (Lippke, 1989). If marketing practices involve consumerism, as Hunt (2007) suggest, an exercise of ethical practical judgment is required. It requires the development of enduring relationships between stakeholders to the judgmental decision (Gibbs, 2006)

Ethical marketing throughout an institution requires professional ethics, institutional ethical policy statements that include values and principles and ethical culture of collegiality and fairness (Gibbs \& Murphy, 2006).

\section{Marketing and Advertising Higher Education, Trends and Competition}

A combination of factors over the past forty years has contributed to colleges and universities to start a race o marketing efforts. Since early 1970's Congress could not continue to support research and growth in higher education as it has done in the 1950's and 1960's (Bok, 2003; Zemsky, Wegner, and Massy, 2005). As a result, among the economic downturn, rapid inflation and raised unemployment, the number of student started to decline.

Colleges and universities had to retool their strategies and a new kind of higher education began to emerge. Competition from for-profit organizations started up; in an effort to reduce cost and be more efficient, online platforms were used by successful models such as University of Phoenix, American InterContinental University and DeVry University. Traditional colleges and universities had to adapt and respond or risk losing students. They had to overcome the adverse environment with new techniques and strategies in a form of marketing and advertising. The strategic marketing plan started to be considered a critical component of the organizations academic mission (Hesel, 2004; Keller, 1983). Good marketing knows the product, it understands the price structure, and it understands how to appeal to consumers based on what is for sale (Kotler, 1999). Good marketing is well researched, highly coordinated, and professionally delivered (McCarthy, 1960). The competition for students is real and so too must be the response. Resources in higher education are always scarce; tight budgets and increased scrutiny require that every dollar be spent wisely and with the greatest chance for maximized returns (Anctil, 2008).

\section{Direct Mail}

With the exception of some elites institutions, most colleges and universities are battling for enrollment. As a result, marketing and advertisement have become key aspects of institutional strategy. A study on today's American colleges and universities reveals that most presidents and their advertising personnel choose direct mailing as the single most effective medium for student recruitment (Burdesnki \& Shanklin, 1987).

It was shown that direct mail is used for recruitment strategy as its most essential use, but also for fund raising, marketing continuing education programs and keeping alumni informed. 
Other tools followed by direct mail, are newspaper, radio, television, magazines, outdoor and transit adds.

Students search service providers have substantially boosted, for instance colleges and university might select the students enrolled in a particular high school on a specific geographical area, that students meet or exceed a minimum grade point average and intend to matriculate at a private institution of higher education. Geodemographic database provides individuals and households in various geographical areas (Curry, 1993; Sachs \& Elston, 1994). A college or university also can receive names of high school students who indicate on their college board examinations that they have some interest in a certain institution.

It was found that the easier it is for a student to respond to a direct mail solicitation from a college or university, the higher the response rate. However, the easier it is for the student to respond the lower the final enrollment rate.

As a consequence, direct mail strategies need to be closely tailored to institutional objectives. Some large universities with great investments and high recruitment goals are better taking a quantity approach making easier response tactics, meanwhile small colleges and universities are better avoiding an easy to apply approach and make them appeal as more elitist.

In the study in reference, it is contradictory that even though direct mailing was considered the most essential tool for student recruitment, most colleges and universities were allocating a bigger portion of their advertising budget to newspapers rather than direct mail.

There are good reasons for direct mail for being the most effective tool, according to Burdesnki \& Shanklin (1987), and they are because they allow college or universities to target their prospective and identify their specific interests. Use of direct mail has continued to increase as written communications continue to increases as well, especially with development of technology. Many colleges and universities use mailing lists that contain information compiled by national testing agencies. Names can be purchased and search criteria can be selected, such as geographical location, size of the institution, programs offered, grade point average, standardize test scores. Many private colleges and universities send eight or more written communications to prospective students ${ }^{1}$.

\section{Financial Aid as a Recruiting Tool}

The decade of the 1990's was influenced by student aid policy and ultimately enrollment management decisions. Student consumerism, public skepticism about value of higher education, institutional concerns for fiscal and enrollment viability and calls for reform for undergraduate education are characteristics of this influence (Coomes, 2000).

The 1990's were the decade of student's loans with the creation of programs such as Pell Grant to Federal Family, Educational Loan Program FFELP and Hope Scholarship and Lifetime Learning Credits.

\footnotetext{
${ }^{1}$ (http://education.stateuniversity.com/pages/1858/College-Recruitment-Practices.html).
} 
Competition is fierce for students and enrollment goals are set high. To meet the demand for students, colleges and universities employed sophisticated marketing techniques and econometric to target aids at groups of students they felt they were most likely to meet enrollment criteria (Coomes, 2000).

The debates about financial aid strategy are contingent upon a complex and standardized approach to students and families financial need and thereby determining eligibility for financial assistance. At many institutions merit aid is used fulfill enrollment strategies and call academically attractive students who are able to pay more of their own tuition. Tuition discounting is a way of merit-based aid that occurs when institutions compete for the best students. Regardless, the typical concern is that a non-need-based merit scholarship diverts resources form lower income students who need assistance to those who do not.

Senior enrollment management and trustees have as an important role to ensure that financial aid technique does not overshadow institutional purposes and priorities. The selectivity rating of an institution correlates to the likelihood that they will offer merit-based aid (McPherson and Schapiro, 1994). As part of techniques, institutions of lesser prestige may award merit-based to high-ability students to fulfill their enrollment goal by tempting student from more selective institutions.

Financial aid has been increasingly used as a recruiting and marketing tool, in special for private institutions in their effort to compete with public institutions. Merit-based scholarships are used to discount tuition as an important tool to increase enrollment ${ }^{2}$.

However, now that institutions can no longer meet full need and are using their own resources to target the most admissible students, applicants recognize that they have the opportunity to bargain for the most favorable student aid award (Coomes, 2000). Offering noneed merit based aid ranks as the 3rd most effective marketing and recruitment strategy for both public and private four-year institutions for reaching institutional goals (Noel-Levitz, 2008). Institutions have multiple goals from academic to sports. Perhaps, the intent is to balance an enrollment portfolio by filling some programs through targeted scholarships.

\section{Discussion and Conclusions}

Students have become the customers for marketing and advertising purposes, and are the most important thing in the institutions strategy. Internal strategies such as faculty motivation are as important as external strategies such as direct mail. Financial aid strategy can affect both internal in terms of economic impact of income and external in terms of prestige and reputation.

Marketing is a valuable tool for institutions and university leaders. It can encourage and expand market participation and share, but also can confuse and divert the mission and values of the institution. It is important for colleges and universities to apply ethical practices in marketing and advertising tools in order to maintain professional ethics, institutional ethical polity statements and ethical culture. As implication to practice, it is highly recommended that institutions perform and ethics marketing audit, approve reports from marketing seniors on marketing ethics, perform

\footnotetext{
${ }^{2}$ (http://education.stateuniversity.com/pages/1858/College-Recruitment-Practices.html)
} 
student surveys on reporting on unethical marketing and perception to reality service. Marketing efforts should be align towards organizational goals, be aware and responsive to stakeholder's needs and requirements, and be dynamic and adaptive with the community rather than reactive.

From different successful marketing tools, studies have shown that direct mail is the most successful tool for recruitment goals; however there are other instruments that need to be address and surprisingly have larger budget allocation than direct mail such as newspaper. Marketing and advertising are likely to become more sophisticated as technology develops. Colleges and universities cannot afford to lose a student and will need to recruit them from their very first point of contact. Traditional recruitment practices will still be around probably with more emphasis on internet-based initiatives. Each institution must adjust their needs to available tools and according to their strategic plan as well as to be creative and aggressive.

Financial aid and tuition discounting are practices to enhance student's admissions from different economic and academic levels. Financial aid in the form of merit-based aid is a strategy that colleges and universities are adopting to attract better qualified students in the programs. It is important that these aids keep their original goal which was helping the unprivileged secure an education.

\section{Bibliography}

Anctil, E.J. (2008). Marketing and Advertising Higher Education. ASHE Higher Education Report, 34(2), 19-30

Burdenski \& Shanklin (1987). Direct Mail Marketing in Higher Education Journal of Direct Marketing 1-2 Spring

College Recruitment Practices. Recruitment Theory and Practices, Nontraditional Enrollees, , Financial Aid as a Recruiting Tool, the Future. (http://education.stateuniversity.com/pages/1858/College-Recruitment-Practices.html)

Coomes, Michael (2000). The Historical Roots of Enrollment Management New Directions for Students Services, no 89. Jossey-Bass Publishers

Gibbs and Murphy (2009). Ethical Marketing of Higher Education: What Might be Done to Encourage its Adoption. Higher Education Management and Policy. Volume 21/3

Kalsbeek and Hossler (2008). Enrollment Management: Financial Aid. College \& University. Volume 84, no 1(2008)

Tareef \& Balas (2010). Marketing in higher Education Institutes: Using Internal Marketing Strategy and Innovation Models. 